\title{
Novel insights into chromosomal conformations in cancer
}

\author{
Ruobing Jia ${ }^{1,2+}$, Peiwei Chai ${ }^{1,2+}$, He Zhang ${ }^{1,2^{*}}$ and Xianqun Fan ${ }^{1,2^{*}}$
}

\begin{abstract}
Exploring gene function is critical for understanding the complexity of life. DNA sequences and the three-dimensional organization of chromatin (chromosomal interactions) are considered enigmatic factors underlying gene function, and interactions between two distant fragments can regulate transactivation activity via mediator proteins. Thus, a series of chromosome conformation capture techniques have been developed, including chromosome conformation capture (3C), circular chromosome conformation capture (4C), chromosome conformation capture carbon copy (5C), and high-resolution chromosome conformation capture (Hi-C). The application of these techniques has expanded to various fields, but cancer remains one of the major topics. Interactions mediated by proteins or long noncoding RNAs (IncRNAs) are typically found using 4C-sequencing and chromatin interaction analysis by paired-end tag sequencing (ChIA-PET). Currently, Hi-C is used to identify chromatin loops between cancer risk-associated single-nucleotide polymorphisms (SNPs) found by genome-wide association studies (GWAS) and their target genes. Chromosomal conformations are responsible for altered gene regulation through several typical mechanisms and contribute to the biological behavior and malignancy of different tumors, particularly prostate cancer, breast cancer and hematologic neoplasms. Moreover, different subtypes may exhibit different 3D-chromosomal conformations. Thus, C-tech can be used to help diagnose cancer subtypes and alleviate cancer progression by destroying specific chromosomal conformations. Here, we review the fundamentals and improvements in chromosome conformation capture techniques and their clinical applications in cancer to provide insight for future research.
\end{abstract}

Keywords: Chromosomal conformations, Cancer, Diagnosis, Treatment, Chromosome conformation capture

\section{Background}

Gene expression in eukaryotic cells is regulated by many different complex mechanisms. In addition to epigenetic alterations (i.e., histone modifications, DNA methylation and noncoding RNA), chromosome conformation can influence gene function.

Chromosomes have unique, high-ordered structures that influence gene function. The higher-ordered genome structure often formed by hierarchical folding. First, the DNA double helix winds around an octamer of histone proteins to create the nucleosome. A beads-on-string fiber with a width of approximately $10 \mathrm{~nm}$ is then formed [1], followed by 30-nm fibers and global structures, and the length of the DNA chain folds to one-hundredthousandth of the nonfolded size.

\footnotetext{
* Correspondence: zhanghe@sjtu.edu.cn; fanxq@sjtu.edu.cn

${ }^{\dagger}$ Equal contributors

'Department of Ophthalmology, Ninth People's Hospital, Shanghai Jiao Tong University School of Medicine, Shanghai, People's Republic of China Full list of author information is available at the end of the article
}

Proteins are involved in the formation of higher-ordered chromosome structures, such as chromosome loops. Some proteins, including special AT-rich sequence-binding protein-1 (SATB1), CCCTC-binding factor (CTCF) and cohesin, play key roles in disease development and recovery. Genes located at long distances from one another can interact through these known and unknown folding mechanisms to produce variable results.

\section{Techniques to detect chromosome conformation}

To better study chromosome conformations, the following two types of techniques have been developed: observation methods and C-techs. Observation methods include fluorescence in situ hybridization (FISH), microscopy (light microscopy or electron microscopy), and nuclear ligation [2]; C-tech methods are more novel and technical. Chromosome conformation capture (3C) was invented in 2002 and was the first member of the C-tech family [3]. Subsequently, $3 \mathrm{C}$ has rapidly advanced to circular chromosome 
conformation capture (4C), chromosome conformation capture carbon copy (5C), high-resolution chromosome conformation capture ( $\mathrm{Hi}-\mathrm{C})$, chromatin interaction analysis by paired-end tag sequencing (ChIA-PET), targeted chromatin capture (T2C), Capture- $\mathrm{C}$ and many others to meet a wider variety of needs (Table 1 ).

Most of above mentioned technologies are based on $3 \mathrm{C}$ technology. After proteins are fixed and crosslinked with formaldehyde, chromatin is cut into 4- to 10 -kb pieces [3] by 6-base recognizing enzymes, such as HindIII [3], EcoRI [4], BglII [5], DdeI [6], DpnII [7] and BamHI [8]. The use of a 4-base recognizing enzyme may be ideal for analyzing a narrow area, but these enzymes create too many small pieces. DNase I has been recently used to enhance the resolution [9]. One megabase is often considered the limit of 3C technologies, but larger distances [10] even those between chromosomes [11] have been reported. Semiquantitative polymerase chain reaction (PCR) is always performed to verify the ligation junctions of interest. $3 \mathrm{C}$ technology is often used to analyze enhancer or insulator activities using CTCF but is limited in its ability to identify unknown regions.

$4 \mathrm{C}$ technology enables the discovery of longer distance co-associations. Unlike the 6-base recognizing enzymes used in 3C, 4-base recognizing enzymes are used to cut chromosomes into 256-bp fragments. First, a single chromosome region of interest is selected, and global chromosomes associated with that region are sequenced. The target genes are amplified and sequenced, and global genome-wide interactions with the chosen fragment can be identified. This process is always described as one-to-all [12]. 4C technology also includes chromosome conformation capture on chromatin immunoprecipitation (ChIP) [13], which is similar to enhanced the chromosome conformation capture on ChIP (e4C) [14] approach that adds an optional ChIP step to test fragment binding to a chosen protein and can be more sensitive. Using 4C-seq [15], we can quickly and comprehensively identify the sequences of interest.
5C can be used to map many interactions among several fragments in a region [16]. After the difficult step of designing hundreds of primers [17], ligation-mediated amplification (LMA) is commonly performed following $5 \mathrm{C}$ instead of PCR, which is commonly performed following $3 \mathrm{C}$ [18]. 5C can provide more detailed information and be used to construct a special network around genes of interest. Hi-C was designed in 2009 to recover ligated fragments using streptavidin to capture global genome-wide interactions, including long-distance interactions [19], and protocols and algorithms have demonstrated that it improves capture range and accuracy [20, 21]. Single-cell Hi$\mathrm{C}$ can be used to analyze differences in chromosome conformation among cells and determine the uniqueness of cells [22]. In addition to chromosomes, ChIA-PET can be used to test global interactions with a chosen protein, such as CTCF [23] or polymerase II (Pol II) [24]. Moreover, new statistical patterns have been identified for ChIA-PET [25]. Additional new C-techs have been developed. Capture-C is a $3 \mathrm{C}$-like technique with high resolution that can capture interactions in cis conformations using oligonucleotide probes [26]. T2C focuses on the target gene and explores its local interactions, thus reducing cost and labor [27], and is widely used to predict local loops [28]. Capture-Hi-C is a many-to-all Hi-C technique with higher resolution because it includes an additional step in which the sequences of interest (baits) are enriched [29]. RNAguided chromatin conformation capture (R3C) is a new method that can be used to precisely study interactions between RNA and DNA [30, 31] (Fig. 1).

Other techniques, mainly developed prior to $3 \mathrm{C}$ techniques, can help to identify chromosomal interactions. FISH, microscopy (light microscopy or electron microscopy), and nuclear ligation [2] are widely used to observe and verify the higher-ordered chromosome organization. ChIA-PET is another advanced technique used to test global interactions with a chosen protein, such as CTCF [23] or DNA Pol II [24]. New statistical tools for ChIAPET analysis have also been developed [25]. The 4D Nucleome Project provides a coherent view of how

Table 1 Techniques used for chromosome conformation capture

\begin{tabular}{|c|c|c|c|c|c|}
\hline Technology & $3 C$ & $4 C$ & $5 C$ & $\mathrm{Hi}-\mathrm{C}$ & ChIA-PET \\
\hline Data & One-one & One-all & Many-many & All-all & Many-many \\
\hline Readout & $P C R$ & $\begin{array}{l}\text { Inverse PCR, } \\
\text { microarrays, } \\
\text { NGS }\end{array}$ & LMA, sequencing & Sequencing & Sequencing \\
\hline Advantages & Simple, cheap & $\begin{array}{l}\text { Relatively } \\
\text { simple, goal- } \\
\text { oriented }\end{array}$ & $\begin{array}{l}\text { Explores interactions among many fragments, reduces } \\
\text { bias, relatively targeted }\end{array}$ & $\begin{array}{l}\text { Genome-wide } \\
\text { interactions }\end{array}$ & $\begin{array}{l}\text { Protein } \\
\text { bonded } \\
\text { interactions }\end{array}$ \\
\hline Limitations & $\begin{array}{l}\text { Laborious, only known } \\
\text { combinations, poor } \\
\text { resolution }\end{array}$ & $\begin{array}{l}\text { Only chosen } \\
\text { regions }\end{array}$ & $\begin{array}{l}\text { Difficult to design hundreds of primers, analyzes only } \\
\text { chosen fragments, some long-distance interactions are } \\
\text { missing }\end{array}$ & $\begin{array}{l}\text { Difficult to sequence } \\
\text { and analyze, } \\
\text { expensive }\end{array}$ & $\begin{array}{l}\text { Analyzes only } \\
\text { chosen } \\
\text { protein }\end{array}$ \\
\hline Ref. & {$[3,10]$} & [12] & {$[17,18,142]$} & [19] & {$[24,25]$} \\
\hline
\end{tabular}

Abbreviations: PCR Polymerase Chain Reaction, NGS Next-Generation Sequencing, LMA Ligation-mediated Amplification 


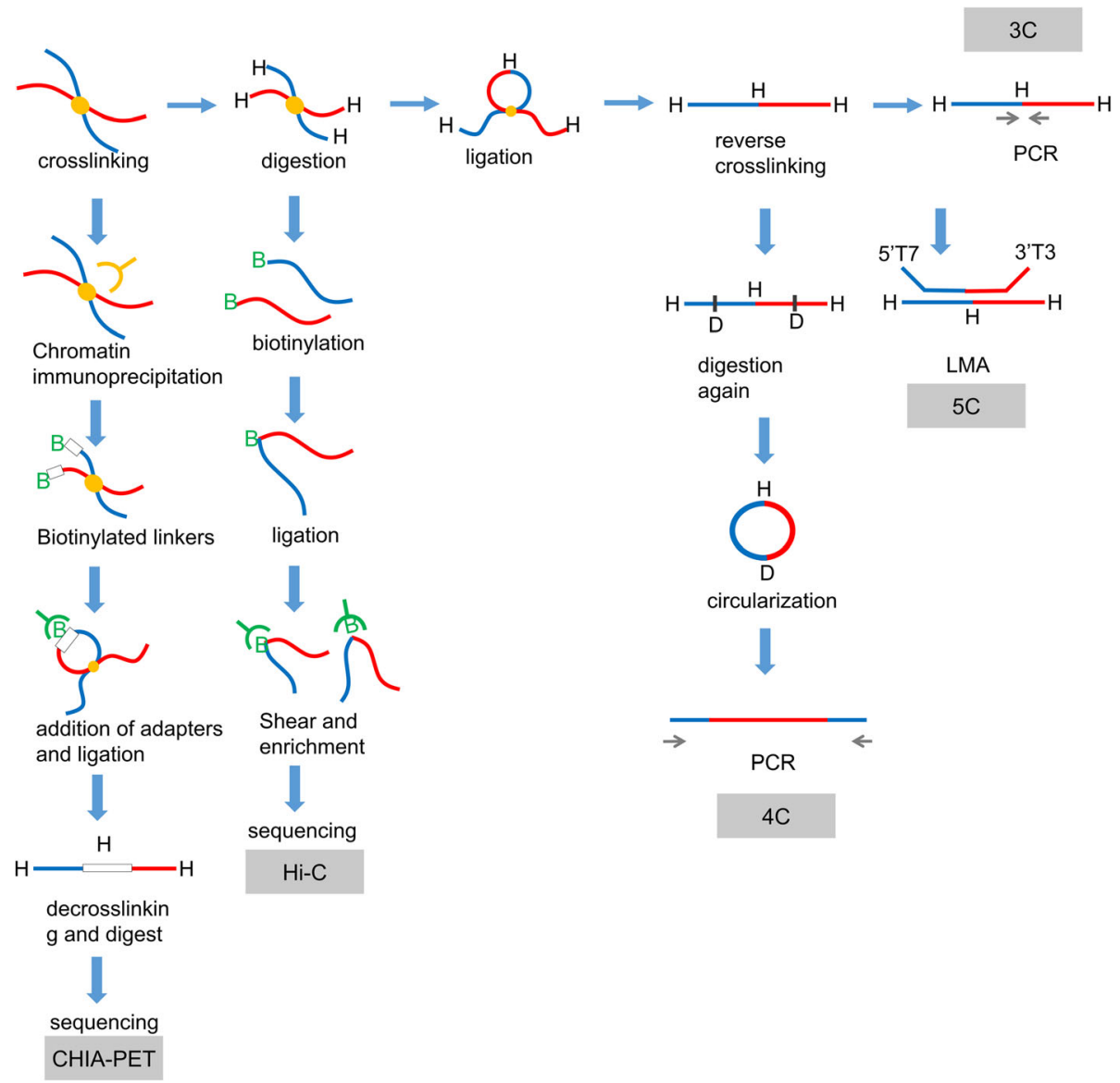

Fig. 1 Overview of 3C-based C-techniques. After crosslinking, chromatin is digested into 4-10 kb pieces by restriction enzymes, followed by ligation and reverse crosslinking to change the crosses into lines. An additional digestion step is added in 4C. LMA is used instead of PCR, which is commonly used in 5C; biotinylation and streptavidin are used in $\mathrm{Hi}-\mathrm{C}$, and a chromatin immunoprecipitation (CHIP) step is added in ChIA-PET

chromosome conformations change, providing insight beyond the static state [32]. One of the newest tools, genome architecture mapping (GAM), shows chromosomal contacts between long-range fragments by sequencing thin nuclear sections [33]. Currently, dCas9 capture with a biotinylated dCas9 step before 3C, RNAseq or proteomics shows chromosomal interactions at a single-copy genomic locus and clarifies trans-regulatory factors [34].

\section{Characteristics and formation of chromosome loops}

Because DNA is packaged and unpackaged in the nucleus, long-range intra- or inter-chromosomal interactions occur, and loops may be formed to stabilize these interactions. In fact, only $7 \%$ of loops occur between the two nearest genes. Of course, chromosome loops are not completely random. The specific DNA topology dictates the sequence [35], flexibility of the chromatin (the ringclosure probability) [36], and other dynamic factors, such as distance, energy [37] and negative DNA supercoiling [38]. A chromosome loop often contains at least two
DNA sequences (for example, one sequence is an enhancer/silencer, and the other is a promoter) and some mediators. Although different cell types have different interactions, enhancers, CTCFs, and actively transcribed chromatin states rich in loops, $79 \%$ of loops span CTCF binding sites, which can prevent enhancer-promoter interactions without loops [39]. CTCF and cohesin are present in over $86 \%$ of loops. All loop domains are separated into 6 subcompartments by 8 histone markers, i.e., histone 3 lysine 36 trimethylation (H3K36me3), histone 3 lysine 27 trimethylation (H3K27me3), histone 3 lysine 4 methylation (H3K4me1), histone 3 lysine 4 dimethylation (H3K4me2), histone 3 lysine 4 trimethylation (H3K4me3), histone 3 lysine 9 trimethylation (H3K9me3), histone 3 lysine 79 dimethylation (H3K79me2), and histone 4 lysine 20 methylation (H4K20me1); the contact domains contain the same markers and change together [40]. In addition, these long-range interactions are inherited from sperm but not the ovum to regulate embryo development and growth [41, 42]. Loops are stable from the G1 to S and G2 phases of the cell cycle [43]. 
The mechanism by which chromosomal loops alter gene regulation remains unclear, but several mechanisms have been proposed, particularly in cancer (Fig. 2). The examination of topologically associated domains (TADs) is another avenue for studying the relationship between chromosome loops and cancers. CTCF is enriched in the boundaries of TADs and can guide interactions by forming loops with cohesin between distantly located sequences [44] to influence gene expression [45]. These loops bind Pol II factories, including Pol II, transcription factors (TFs) and co-TFs [46]. CTCF and cohesin have been widely reported as the most common and important protein mediators $[39,40,47]$. Estrogen receptor $\alpha(E R \alpha)$ is an estradiol (E2)-dependent mediator that binds E2 in the cytoplasm and is then translocated to the nucleus to activate Pol II and recruit forkhead box A1 (FoxA1) and activator protein (AP)-2 $\gamma$ [48-50]. Pol II can mediate interactions between enhancers and promoters and between distinct promoters [51], indicating that promoters can act as enhancers [24]. New mediators and mechanisms have been reported. Mediator complex subunit 1 (MED1) forms loops only when it is phosphorylated; phosphorylated MED1 facilitates loop formation by FoxA1, Pol II and TATA-box binding protein (TBP) [52]. Cut-like homeobox 1 (CUX1) is another mediator that can recruit Pol II via a new mechanism; at normal concentrations, CUX1 mediates interactions between promoters and several enhancers, but the number of binding sites decreases when the dosage of CUX1 is halved [53]. Binding of lncRNA to the polycomb repressive complex may increase the chance of interactions [54] or recruit a mediator protein to form long-range interactions [30]. Most loops form

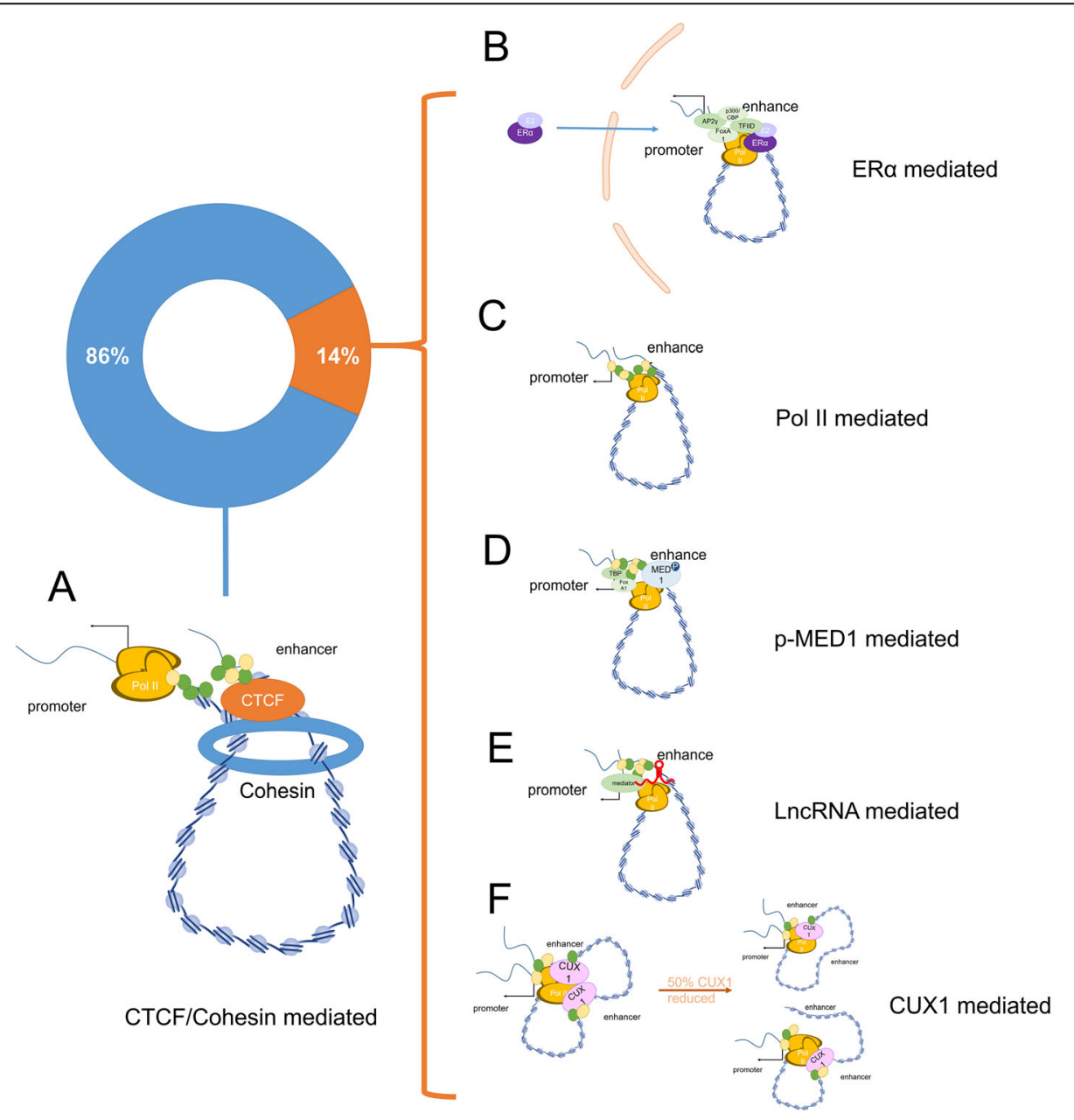

Fig. 2 Several mechanisms for forming chromosomal loops in cancer. Pol II (orange), transcription factors (green) and co-transcription factors (yellow) are always recruited by long-range loop mediators in transcription factories. a Most loops are mediated by CTCF and cohesin, with or without other mediators. b ERa is another common mediator that functions after binding E2 and entering the nucleus. c Pol II can mediate long-range loops between promoters, suggesting that promoters sometimes act as enhancers. d MED1 acts as a chromosomal loop mediator only when it is phosphorylated. e Some IncRNAs can mediate chromosomal loops. $\mathbf{f}$ CUX1 is special in that it mediates the binding of two enhancers to one promoter, and when its expression is reduced to $50 \%$, it mediates the binding of one enhancer to one promoter 
between promoters and promoters or promoters and enhancers, whereas a minority between promoters and insulators [55]; some loops are even involved in chromosomal translocations [56].

\section{Roles of chromosomal conformations in cancer}

The rapid development of new techniques makes it possible to determine important roles of chromosomal conformations in many fields, especially in cancer. Specific proteins mediate the chromosome loops between different cancer-related genes (including their promoters) and an enhancer or a repressor to regulate gene transcription and influence the biological behaviors of carcinomas. In this review, we discuss the function of these loops and the possible clinical applications of these fatal chromosome conformations in diagnosis and treatment (Table 2).

\section{Chromosomal conformations in cancer}

Two research strategies are used to identify new chromosomal conformations and their characteristics. C-techs are used to identify classical interactions that are mediated by typical proteins, and $\mathrm{Hi}-\mathrm{C}$ is currently used to identify chromatin loops between cancer risk-associated singlenucleotide polymorphisms (SNPs) found by genome-wide association studies (GWAS) and their target genes.

\section{Classical long-range interactions}

ChIA-PET, CHIP-seq and 4C-seq are widely used to identify long-range interactions that are mediated by proteins or lncRNAs. In addition, most interactions are found in prostate cancer, breast cancer and leukemia, which will be discussed in detail in the following section.

The abnormal activation of the androgen receptor $(\mathrm{AR})$ is a major cause of androgen-dependent prostate cancer (ADPC) and its advanced stage, i.e., castrationresistant prostate cancer (CRPC), in which the AR acts as a transcription factor. Some AR binding regions are far from the AR and associate with the AR through chromosome loops. In general, there are two ways for AR-driven chromosome looping to function in neoplasia [57]. First, AR can increase spatial association of the transmembrane protease, serine 2 (TMPRSS2) gene and ETS-related gene (ERG) and mediate TMPRSS2-ERG gene fusion [58], which is a clinical marker of prostate cancer. Moreover, the loops can associate long-range genes, which are often enhancers, with cancer-related gene promoters and change their expression [59]; this process is mediated by AR-collaborating TFs [60]. In addition, changes in certain active histone modifications, such as H3K4me1, H3K4me2 and histone H3 acetylation, are also important in forming chromosomal conformations. For example, ERG disrupts the AR by activating the H3K27 methyltransferase EZH2 [61]. Three CRPC-specific enhancers interact with the AR target gene ubiquitin-conjugating enzyme E2C (UBE2C) through chromosome loops mediated by FOXA1 and phosphorylated MED1, which leads to high expression of UBE2C and makes CRPC an incurable disease, unlike ADPC [52]. Similar loops can be observed between the AR binding sites and the promoters of prostate-specific antigen (PSA) [62], which is one of the most important genes in prostate cancer. Overexpression of ERG may also contribute to a change in chromosome topology [63]. In addition, the long-distance interactions among TFF3-ERG, MOXD1-FYN, MOXD1-SERPINB9, and MOXD1-HEY2 were specifically found in prostate cancer cells by a Hi-C analysis [64]. TADs are smaller and more plentiful in the prostate cancer cell genome, and the boundaries of these TADs attract more CTCF binding and H3K4me3 [65], providing more opportunities to form long-range interactions. In fact, these differences lead to cancer-related interactions between enhancers and promoters that occur in epigenetically deregulated domains [65]. lncRNAs are also involved; for example, PCGEM1 and PRNCR1 (PCAT8) mediate the enhancer-promoter chromosome loops and promote AR activation [66].

Chromosome conformations also influence tumorigenesis and breast cancer development. The long-range interactions of insulin-like growth factor-binding protein 3 (IGFBP3), a key gene in the development of breast cancer [67], are increased in breast cancer cells relative to those in normal cells [68]. The association between IGFBP3 with epidermal growth factor receptor (EGFR), another breast cancer-related gene, may contribute to tumorigenesis in a manner similar to the long-range interactions between IGFBP3 and breast carcinoma amplified sequence (BCAS1-4) in MCF7 cells [68]. ER $\alpha$ is another important mediator of long-range interactions in breast cancer. ER $\alpha$ was first reported to mediate longdistance interactions between GREB1 and the trefoil factor 1 (TFF1) gene promoter with the help of FOXA1 and AP-2 $\gamma$ [48-50]. Several other cofactors, including GATA3 [69], TLE1 [70], and PBX1 [71], also play roles in this dramatic process. The TF CTCF without cohesin binding sites is very rich in ER $\alpha$ binding sites and mediates enhancer-promoter loops [72]; a few sites have both cohesin and ER $\alpha$ but rarely CTCF [73]. A recent $\mathrm{Hi}-\mathrm{C}$ experiment showed that many gene sites interacted with $\mathrm{ER} \alpha$, including cancer suppressor genes EGR1 and TGFBR2, apoptosis genes DAXX and BCL2L1, and densely mapped, distant estrogen-responsive elements located in $17 q 23$ and $20 q 13$ [74]. Another Hi-C study showed that runt-related transcription factor 1 (RUNX1) contributes to local interactions rather than long-range interactions in MCF7 cells [75]. Due to the development of ChIA-PET, more ER $\alpha$-mediated interactions deeply involved in breast cancer have been identified [76]. 
Table 2 Summary of chromosomal interactions in cancer

\begin{tabular}{|c|c|c|c|c|c|c|}
\hline \multirow{2}{*}{$\frac{\text { Cancer }}{\text { Prostate cancer }}$} & \multicolumn{2}{|c|}{ Typical interactions } & \multirow{2}{*}{$\begin{array}{l}\text { Mediators } \\
\text { FOXA1 and } \\
\text { phosphorylated } \\
\text { MED1 }\end{array}$} & \multirow{2}{*}{$\begin{array}{l}\text { Therapeutic targets } \\
\text { PI3K/AKT/ } \\
\text { phosphorylated MED1 } \\
\text { pathway }\end{array}$} & \multirow{2}{*}{$\begin{array}{l}\text { Potential drugs } \\
\text { Carvacrol, ipatasertib, } \\
\text { abiraterone acetate }\end{array}$} & \multirow{2}{*}{$\frac{\operatorname{Ref}}{[52]}$} \\
\hline & $\begin{array}{l}\text { CRPC-specific } \\
\text { enhancers }\end{array}$ & UBE2C & & & & \\
\hline & PSA enhancer & PSA promoter & $\begin{array}{l}\text { AR/PCGEM1 and } \\
\text { PRNCR1 (PCAT8) }\end{array}$ & AR & $\begin{array}{l}\text { Sigma1 inhibitor, ASC-J9, cis- } \\
\text { platin, niclosamide, EPI-001, }\end{array}$ & $\begin{array}{l}{[62]} \\
{[66]}\end{array}$ \\
\hline & TFF3 & ERG & ERG & ERG binding domain & ERG inhibitory peptides & [64] \\
\hline & MOXD1 & FYN/SERPINB9/HEY2 & & & & \\
\hline & $2 \mathrm{p} 11.2$ & CAPG & / & / & / & [90] \\
\hline & $6 q 22.1$ & RFX6/GPRC6A & & & & \\
\hline & $1 q 32.1$ & NFASC & & & & \\
\hline & $8 q 24$ & MYC & & & & \\
\hline \multirow[t]{4}{*}{ Breast cancer } & IGFBP3 & EGFR/MCF7/BCAS1-4 & / & / & / & [68] \\
\hline & GREB1 & TFF1 promoter & ERa & / & / & $\begin{array}{l}{[48-} \\
50]\end{array}$ \\
\hline & ERa & $\begin{array}{l}\text { EGR1/TGFBR2/DAXX/ } \\
\text { BCL2L1 }\end{array}$ & / & / & / & [74] \\
\hline & $\begin{array}{l}\text { ZEB2 promoter } \\
\text { 1a }\end{array}$ & ZEB2 promoter 1b & $A P-1$ & AP-1, ZEB2 and ERK/Akt & $\begin{array}{l}\text { AP1-C301-S, SR 11302, valproic } \\
\text { acid, U0126, miR-132 }\end{array}$ & [77] \\
\hline \multirow[t]{6}{*}{$\begin{array}{l}\text { Hematologic } \\
\text { neoplasms }\end{array}$} & $\begin{array}{l}\text { GATA2 } \\
\text { enhancer }\end{array}$ & EVl1 & / & EVI1 & Pyrrole-Imidazole Polyamide 1 & [79] \\
\hline & $B C R$ & $A B L$ & / & $\begin{array}{l}\text { BCR-ABL fusion gene, } \\
\text { BCL2 }\end{array}$ & ZINC12891610 (hit2), venetoclax & [136] \\
\hline & HoxA & $\begin{array}{l}\text { Genes on chromosome } \\
14\end{array}$ & TFBS & / & / & [81] \\
\hline & IGF1R promoter & IGF1R enhancer & IRAIN & / & / & [82] \\
\hline & $\begin{array}{l}\text { RUNX1 } \\
\text { promoters }\end{array}$ & RUNX1 enhancer & RUNXOR & / & / & [56] \\
\hline & $\begin{array}{l}\text { Unknown } \\
\text { promoters }\end{array}$ & Unknown enhancers & CUX1 & CUX1 & / & [53] \\
\hline \multirow[t]{2}{*}{ Colorectal cancer } & MYC promoter & 335-kb enhancer & $\begin{array}{l}\text { CCAT1-L } \\
\text { CTCF }\end{array}$ & / & / & [84] \\
\hline & $\begin{array}{l}\text { MYC promoter } \\
\text { MECOM } \\
\text { ETS1 }\end{array}$ & $\begin{array}{l}\text { rs6983267 (contains } \\
\text { multiple enhancers) } \\
3 \text { q26.2 } \\
11 \mathrm{q} 23\end{array}$ & CCAT1 & / & / & [95] \\
\hline Pancreatic cancer & rs386772267 & DIS3 promoter & An allele-specific TF & / & / & [96] \\
\hline Melanoma & MITF & BRN2/CDKN1A/TBX3 & / & MITF & $\begin{array}{l}\text { HIV1 protease inhibitor } \\
\text { nelfinavir }\end{array}$ & [86] \\
\hline $\begin{array}{l}\text { Thyroid } \\
\text { carcinoma }\end{array}$ & $\begin{array}{l}\text { rs965513 } \\
\text { mutant }\end{array}$ & $\begin{array}{l}\text { FOXE1 and PTCSC2 } \\
\text { promoter }\end{array}$ & / & / & / & [97] \\
\hline \multirow[t]{2}{*}{ Gliomas } & $\begin{array}{l}\text { FIPL1L1 } \\
\text { enhancer }\end{array}$ & PDGFRA & $\begin{array}{l}\text { CTCF altered by } \\
\text { mutant IDH }\end{array}$ & / & / & [98] \\
\hline & rs73001406 & DDX6 promoter & / & / & / & [99] \\
\hline Neurofibromatosis & NF1 & 1-Mb fragment nearby & / & / & / & [87] \\
\hline $\begin{array}{l}\text { Adenoid cystic } \\
\text { carcinoma }\end{array}$ & MYB promoter & MYB enhancer & $\begin{array}{l}\text { ACCMYB-TGFBR3 } \\
\text { translocation }\end{array}$ & Super-enhancer BRD4 & JQ1 & [88] \\
\hline $\begin{array}{l}\text { Testicular germ } \\
\text { cell tumors }\end{array}$ & $\begin{array}{l}\text { Predicted } \\
\text { GATA4 } \\
\text { promoter } \\
1 \mathrm{q} 22 \\
11 \mathrm{q} 14.1\end{array}$ & $\begin{array}{l}20 q 13.2 \\
15 q 25.2 \\
15 q 22.31\end{array}$ & / & / & / & [100] \\
\hline
\end{tabular}


Triple-negative breast cancer (TNBC) is a highly malignant breast cancer that is not associated with ER $\alpha$. Activator protein 1 (AP1) is activated by tumor necrosis factor alpha (TNFo) and binds the long-range promoter of zinc finger E-box-binding homeobox 2 (ZEB2) to influence its expression, resulting in epithelial-mesenchymal transitions that are considered a potential novel therapeutic target for TNBC [77]. CTCF mediates the binding of the unmethylated imprinting control region to the IGF2 promoter region in the breast cancer MCF7 cell line [52]. An antisense noncoding RNA, i.e., IRAIN, is involved in the allele-switch pattern in breast cancer [31]. However, in many cases, more inter-chromosomal interactions appear in normal cells than in tumor cells [78].

The Philadelphia chromosome, which is an interchange between chromosomes 9 and 22 that produces a $\mathrm{BCR}-\mathrm{ABL}$ fusion gene that can be found in almost all types of chronic myelogenous leukemia (CML), some types of acute lymphoblastic leukemia (ALL) and several types of acute myelocytic leukemia (AML), is a key example of the role of chromosome conformations in leukemia. Long-range interactions play an important role in this disease.

In AML with inv.(3)/t(3;3), an enhancer that interacts with GATA2 in normal cells, loses its connection to GATA2 and re-interacts with (active) EVI1, leading to cancer [79]. Translocation partner genes (TPGs) are located in transcriptional activity-related regions and mediate interactions among higher-order chromosome structures. This phenomenon was observed in both GM06990 and K562 cell lines [80]. In addition, it was determine the position of morbigenous translocations and revealed the global interactions of the HoxA gene on chromosome 7 [81]. IncRNAs, such as IRAIN, participate in the formation of intra-chromosomal loops; lncRNAs help the IGF1R promoter contact the enhancer, which is located $150 \mathrm{~kb}$ away [82]. RUNXOR can mediate the interaction between the RUNX1 promoters and its enhancer by forming a RUNX1 intra-chromosome loop and is involved in chromosomal translocation [56]. CUX1, a haploinsufficient TF, is a new mediator that contributes to long-range interactions between enhancers and sites close to the TSS in hematologic neoplasms and solid tumors; 32-49\% of CUX1 co-localizes with RNA Pol II, and 34$70 \%$ of CUX1 co-localizes with EP300, a transcriptional co-activator. However, the cohesion complex appears more frequently, further demonstrating that CUX1 contributes to chromatin loops [53].

Chromosomal conformations play important roles in many malignant tumors. CTCF binding sites can change in colorectal cancer and are considered alterable chromosomal conformations [83]. In addition, IncRNA CCAT1-L together with CTCF can mediate a 335-kb interaction between the MYC promoter and its enhancer in colorectal cancer [84]. Microphthalmia-associated transcription factor (MITF) plays a major role in the development and metastasis of melanoma, another highly malignant tumor [85]. Three MITF-related chromosome loops (with BRN2, CDKN1A and TBX3) have been found in both cell lines and patient blood samples. This study was the first confirmation of long-range chromosome loops in melanoma and provided valuable prospects for diagnosis by examination of circulating immune cells [86]. A study investigating neurofibromatosis found a $1-\mathrm{Mb}$ fragment containing the neurofibromatosis type I (NF1) gene that interacts with another nearby $1-\mathrm{Mb}$ fragment recorded in the HindIII and NcoI-maps ([87]) using Hi-C data.

An interesting feedback loop exists in adenoid cystic carcinoma in which MYB protein-bound enhancers can interact long range to activate the promoter of MYB, and ACCMYB-TGFBR3 translocation also places the superenhancer in contact with the promoter of MYB [88].

\section{Loops involving cancer risk-associated SNPs}

Cancer risk-associated SNPs are a leading area of study in oncomolecular biology, and long-range loops at these high-risk sites may be valuable. Some researchers combined $\mathrm{Hi}-\mathrm{C}$ and occasionally $4 \mathrm{C}$-seq with GWAS to identify additional novel and meaningful loops in which a new browser enables easy visual examination [89].

In prostate cancer, a capture $\mathrm{Hi}-\mathrm{C}$ experiment revealed that some high-risk SNPs interact with their longdistance target genes, including CAPG, C2orf43, RFX6, NFASC, MYC and AGAP7P, through chromosome loops [90]. 4C-seq with GWAS was used to identify a risk locus for prostate cancers (LNCaP and C4-2B cells), and MYC and POU5F1B were ranked the highest, followed by CD96, PVT1, GSDMC, CXorf36, RRP12, USP14 and SMIN3, which may exhibit abnormal chromatin looping [91]. These techniques also revealed the following key pathways: the TFG-beta signaling pathway, p53 pathway and hypoxia response via HIF activation; which are considered highly important in the development of prostate cancer [91]. In breast cancer, $\mathrm{Hi}-\mathrm{C}$ and GWAS have been combined to identify risk loci, including the protein-coding genes IGFBP5, KLF4, NSMCE2, and MYC, and the IncRNAs DIRC3, PVT1, and CCDC26, which are associated with CTCF [92, 93]. Capture Hi-C tech has also been applied to the study of colorectal cancer and used to identify long-range interactions between rs6983267 (later shown to contain multiple enhancers [94]) and a MYC promoter mediated by the MYCrelated lncRNA CCAT1. Similar loops were identified between 3q26.2 and MECOM and between 11q23 and ETS1 [95]. The pancreatic cancer risk locus rs386772267 suppresses the expression of DIS3 via the loop between rs386772267 and the promoter of DIS3 with an allele- 
specific TF [96]. In papillary thyroid carcinoma (PTC), a combination of low-penetrance genes is critical, and one of these genes has SNP rs965513. Its mutants (i.e., SNPs rs7864322, rs12352658, rs7847449, and rs10759944) interact with a promoter shared by FOXE1 and PTCSC2 and act as enhancers [97]. Gliomas also display SNPmediated interactions in which the oncogene PDGFRA is changed by CTCF-related chromosome folding [98]. Other interactions among enhancers, SNP rs73001406, and the DDX6 gene promoter affect cancer risk [99]. By combining GWAS and Hi-C, 19 new risk loci were identified in testicular germ cell tumors, including interactions between a predicted GATA4 promoter and 20q13.2, between $1 \mathrm{q} 22$ and $15 \mathrm{q} 25.2$, and between $11 \mathrm{q} 14.1$ and 15q22.31 [100].

\section{Chromosomal conformations lead to malignancy in cancer}

Interactions between promoters and enhancers (or promoters sometimes) can influence gene expression. Some interactions have been reported to specifically change tumor behavior, and these effects depend on the target genes. Some target genes are known to be key in cancer: some are involved in chromosomal translocation [56], and others may be novel diagnostic targets.

Some examples include loops mediated by phosphorylated MED1 [52], the lncRNAs PCGEM1 and PRNCR1 [66], and MYB [88] that strongly promote cell growth. When the loops are disrupted, cancer growth is robustly inhibited in mouse models. The lncRNA IRAIN changes tumor migration ability [31]. When the interactions between GATA2 and EVI1 are disrupted, cancer cells have higher apoptosis rates [79], and CUX1 alters the expression of a cluster of genes and the cell cycle to promote cell proliferation [53]. However, long-range loops enable expression of PSA [62] and overexpression of oncogenic TFs [64].

\section{Potential diagnostic tools and therapeutic targets based on chromosomal conformations}

Newly discovered loops could be used as novel diagnostic markers. These newly discovered interactions contribute to previously unknown pathways and may be potential therapeutic targets. There are many applications for the identification of chromosomal conformations in diagnosis and therapy.

\section{Diagnostic targets}

$\mathrm{Hi}-\mathrm{C}$ is a new tool that can be used to detect chromosomal aberrations and copy number variations in human cancer samples (for example, glioblastoma and anaplastic astrocytoma) to identify oncogene amplification, tumor suppressor gene deletion, fusion genes, and balanced/unbalanced structural rearrangements [101].
In prostate cancer, new loops with specific histone modifications may serve as new diagnostic markers; the TMPRSS2-ERG fusion has been used as a marker in diagnosis and risk assessment for many years, even before chromatin loops were identified as the culprit [102]. Some clinical trials have treated the TMPRSS2-ERG fusion gene as a biomarker; this gene can correct most of the false-negative results of the prostate cancer antigen 3 (PCA3) test, can act as a supplement to the serum PSA test $[102,103]$ and is associated with a poor outcome [104]. But deeper studies are needed to determine whether newly identified lncRNAs could be used as markers of breast cancer and AML.

In CML, the BCR-ABL fusion gene is often indicative of a poor prognosis, while other mutations lead to varying sensitivity to chemotherapy drugs according to European LeukemiaNet recommendations 2013 [105]. In addition, due to the characteristics of $3^{\prime}$ and $5^{\prime}$ TPG, disease-causing fusion genes may be predictive and used in diagnosis [80]. Human leukemia can be classified according to the different chromosome conformations. By mapping the HOXA gene cluster using the $5 \mathrm{C}$ technique and analyzing the gene cluster using 3D DNA diseasesignature predictor, the MLL-fusion protein can be classified as wild-type, and the subtypes of leukemia can be classified according to their different MLL-fusion partners with high accuracy; thus, the MLL-fusion protein can be used as a novel marker, but this has been verified only in cell lines, and a clinical trial is necessary [106]. Studies have also identified new risk loci, such as NCK1, NCAPH2 and L3MBTL4, in B-cell malignancies (BCMs), including chronic lymphocytic leukemia, Hodgkin lymphoma and multiple myeloma [107]. Moreover, as CUX1 is inactivated in more than half of high-risk myeloid leukemia cases [108], it can be used as a biomarker of poor prognosis.

In melanoma, MITF-related loops identified in circulating tumor cells can be used to noninvasively detect cancer [86] and predict a poor prognosis [109], as shown in humans. In gliomas, 11q23.3 was identified as a susceptibility locus that is closely related to abnormal chromosome conformations [99], and rs965513 was identified as a risk factor in papillary thyroid carcinoma [97].

Many characteristic features have been found in different cancers and other diseases, such as autoimmune disease [110] and obesity [111]. An increasing number of candidate genes have been proposed, but they have not yet been commonly used as clinical markers. Applying these techniques remains challenging.

\section{Therapeutic targets}

As previously discussed, many interactions and new functions of RNA and proteins have recently been found in many cancers, and these discoveries may present new 
therapeutic targets. In addition to small-molecule inhibitors of specific targets that may be predicted by drugs, plasmids carried by histidine-lysine peptide (HKP) enable the use of siRNA as a new agent for targeting specific sequences [112]. Here, we mention some therapeutic targets and drugs, and we describe completed clinical trials and studies with significant effects in vitro and in mice.

As androgen deprivation therapy for prostate cancer often leads to eventual resistance, there is an urgent need for new therapies. The chromosomal loops of UBE2C that are mediated by MED1 in both AR-positive and ARnegative CRPC, as discussed above, were reported to be a new therapeutic target in addition to the PI3K/AKT/phosphorylated MED1 pathway [52]. In clinical and experimental trials, many small-molecule inhibitors have been effective in targeting the AKT and P13K pathways in prostate cancer, including but not limited to carvacrol [113], ipatasertib [114], and abiraterone acetate [115]; phase III trials of abiraterone acetate have been completed and showed a benefit in CRPC patients pre- or postchemotherapy [116]. Additionally, AR-targeted therapies have also had great success; the small molecule Sigma1 inhibitor suppresses AR function and further suppresses prostate cancer in vivo and in vitro [117]. Anti-AR drugs, such as cisplatin, niclosamide [118], ASC-J9 [119], EPI001 [120], and even miRNA [121] or IncRNA [122, 123], also suppress prostate cancer [124]. Cisplatin was investigated in a multicenter phase II trial and was shown to be a safe, feasible and active therapy [125]. Gene fusions, such as TMPRSS2-ERG, are often the result of doublestrand DNA breaks and error-prone DNA repair, mainly through the error-prone non-homologous end-joining pathway and we found that small-molecule inhibitors and siRNAs targeting this pathway decrease TMPRSS2-ERG gene fusion [126]. Other treatments with clinical potential include those that target the key enzyme EZH2 via its inhibitors DZNep [127] and GSK126 [128]; similarly, ERG inhibitory peptides (EIPs) specifically target the ERG binding domain [129].

In TNBC, C-techs have not only provided evidence that AP1 mediates the loop of the ZEB2 promoters but also identified AP-1, ZEB2, and ERK/Akt signaling as potential drug targets [77]. Therefore, the AP1 inhibitors AP1-C301-S and SR 11302 [130]; ERK/Akt inhibiting drugs, such as valproic acid and U0126 [131]; and miR132, which targets ZEB2 [132], may be potential drugs; a phase I/II trial of valproic acid was completed and showed the ability of valproic acid to potentiate the effects of epirubicin [133].

Inhibitors that target key proteins in chromosome loops may be novel drugs for the treatment of hematologic neoplasms. For example, pyrrole-imidazole polyamide 1 can target and decrease the expression of
EVI1 [134], while GZD856 [135], ZINC08764498 and ZINC12891610 are unique Bcr-Abl fusion gene inhibitors [136]. Venetoclax inhibits BCL2 (an overexpressed cancer-related gene in $\mathrm{BCM}$ ) [107], and it has received global approval as an oral medicine while under study in two phase III trials [137].

In melanoma, drugs targeting MITF, such as the HIV1 protease inhibitor nelfinavir, can decrease the formation of loops [138]. BET bromodomain inhibitors, such as JQ1 [139], which can suppress the super-enhancer BRD4 [140], may be developed into treatments for ACC. Moreover, the cancer inhibiting role of DIS3 could be critical for the design of new drugs [96].

However, even with such promising targets and treatments, much work is needed to identify drugs that target each loop of interest.

\section{Conclusions}

Long-range interactions play an increasingly significant role in the development of malignant tumors. An increasing number of long-range interactions have been discovered in prostate cancer, breast cancer, hematologic neoplasms and other cancers and may serve as new diagnostic and therapeutic targets.

Currently, we can study interactions between only two fragments of DNA due to the limitations of available techniques. To determine the underlying mechanisms of cancer onset and progression, we must develop tools for broader analysis. The question of how chromosomes fold and loop is fascinating and has attracted the attention of scientists from many fields, including those studying cancer. As discussed above, we know that risk loci and certain key genes are "hot spots" in which chromosome conformation changes can be reliably found. In addition to these sites, many different mutations of oncogenes and tumor suppressor genes have been detected in cancers. We can surmise that typical cancer-related genes may encompass a new category of chromosome-conformation-related protein binding sites; the binding of these sites leads to chromosome conformation changes, subsequent gene function changes and possibly new pathogenic mechanisms. The use of C-techs may also help to identify more new cancer-related genes. We can then concentrate on the development of small molecule drugs that target these new genes or mechanisms because novel targeting drugs are at the forefront of cancer research and greatly contribute to medical development.

It is likely that there are more unknown proteins and RNAs (or known proteins and RNAs with unknown functions) that mediate these interactions; we call these proteins and RNAs new loop organizers. These undiscovered loop organizers might underlie more new mechanisms and pathways. New loop organizers and their foundations alike may yield new diagnostic and 
therapeutic targets. Moreover, there are many elements involved in forming long-range interactions, including lncRNAs and proteins, that cannot all be targeted simultaneously in new therapies. However, key elements that alter other elements when targeted must be identified to increase the efficacy of oncotherapy, similar to the idea of "one vehicle with multiple satellites". There have been some attempts to target key lncRNAs in oncotherapy [141], and if we develop new therapies related to highorder chromatin conformations based on this idea, we may create a closer link between chromatin conformation and clinical applications.

Future studies should explore how chromosome conformation changes can become a tool for clinical diagnosis and improved therapies.

\section{Abbreviations}

3C: Chromosome conformation capture; 4C: Circular chromosome conformation capture; 5C: Chromosome conformation capture carbon copy; ADPC: Androgen-dependent prostate cancer; ALL: Acute lymphoblastic leukemia; AML: Acute myelocytic leukemia; AR: Androgen receptor; BCAS14: Breast carcinoma amplified sequence; BCM: B-cell malignancies; ChIAPET: Chromatin interaction analysis by paired-end tag sequencing; CHIP: Chromatin immunoprecipitation; CML: Chronic myelogenous leukemia; CRPC: Castration-resistant prostate cancer; CTCF: CCCTC-binding factor; CUX1: Cut-like homeobox 1; E2: Estradiol; e4C: Enhanced chromosome conformation capture-on-ChIP; EGFR: Epidermal growth factor receptor; ERG: ETS-related gene; ERa: Estrogen receptor a; FISH: Fluorescence in situ hybridization; FoxA1: Forkhead box A1; GAM: Genome architecture mapping; GATA1: GATA-binding factor 1; GWAS: Genome-wide association studies; H3K27me3: Histone 3 lysine 27 trimethylation; H3K36me3: Histone 3 lysine 36 trimethylation; H3K4me1: Histone 3 lysine 4 methylation; H3K4me2: Histone 3 lysine 4 dimethylation; H3K4me3: Histone 3 lysine 4 trimethylation; H3K79me2: Histone 3 lysine 79 dimethylation; H3K9me3: Histone 3 lysine 9 trimethylation; H4K20me1: Histone 4 lysine 20 methylation; Hi-C: High-resolution chromosome conformation capture; HKP: Histidine-lysine peptide; IGF2: Insulin-like growth factor 2; IGFBP3: Insulin-like growth factor-binding protein 3; LMA: Ligation-mediated amplification; IncRNAs: Long noncoding RNA; MED1: Mediator complex subunit 1; MITF: Microphthalmia-associated transcription factor; NGS: Nextgeneration sequencing; PCR: Polymerase chain reaction; Pol II: Polymerase II; PSA: Prostate-specific antigen; PTC: Papillary thyroid carcinoma; R3C: RNAguided chromatin conformation capture; RUNX1: Runt-related transcription factor 1; SATB1: Special AT-rich sequence-binding protein-1; SNPs: Singlenucleotide polymorphisms; T2C: Targeted chromatin capture; TAD: Topologically associated domain; TBP: TATA-box binding protein; TF: Transcription factor; TFF1: Trefoil factor 1; TNBC: Triple-negative breast cancer; TNFa: Tumor necrosis factor alpha; UBE2C: Ubiquitin-conjugating enzyme E2 C; ZEB2: Zinc finger E-box-binding homeobox 2

\section{Acknowledgements}

Not applicable.

\section{Funding}

This work was supported by the National Natural Science Foundation of China (31470757), the ShuGuang Project of Shanghai Municipal Education Commission and Shanghai Education Development Foundation (17SG19), the Outstanding Yong Medical Scholar of Shanghai Municipal Commission of Health and Family Planning(2017YQ067), the Program for Professor of Special Appointment (Eastern Scholar) at the Shanghai Institutions of Higher Learning (1410000159), the SMC-ChenXing Yong Scholar Program (2014, Class B), the Shanghai Municipal Education Commission-Gaofeng Clinical Medicine Grant (20161317), the Science and Technology Commission of Shanghai (17DZ2260100) and the Outstanding Yong Scholar Grant of Shanghai JiaoTong University School of Medicine (16XJ11002).

\section{Availability of data and materials}

Not applicable.

\section{Authors' contributions}

$\mathrm{HZ}$ and XF provided direction and guidance throughout the preparation of this manuscript. RJ collected and interpreted studies and was a major contributor to the writing and editing of the manuscript. PC reviewed and made significant revisions to the manuscript. All authors read and approved the final manuscript

\section{Ethics approval and consent to participate}

Not applicable.

\section{Consent for publication}

Not applicable.

\section{Competing interests}

The authors declare that they have no competing interests.

\section{Publisher's Note}

Springer Nature remains neutral with regard to jurisdictional claims in published maps and institutional affiliations.

\section{Author details}

'Department of Ophthalmology, Ninth People's Hospital, Shanghai Jiao Tong University School of Medicine, Shanghai, People's Republic of China. ${ }^{2}$ Shanghai Key Laboratory of Orbital Diseases and Ocular Oncology, Shanghai, People's Republic of China.

Received: 27 April 2017 Accepted: 6 November 2017

Published online: 17 November 2017

\section{References}

1. Bascom G, Schlick T. Linking chromatin fibers to gene folding by hierarchical looping. Biophys J. 2017;112(3):434-45.

2. Cullen KE, Kladde MP, Seyfred MA. Interaction between transcription regulatory regions of prolactin chromatin. Science. 1993;261(5118):203-6.

3. Dekker J, Rippe K, Dekker M, Kleckner N. Capturing chromosome conformation. Science. 2002;295(5558):1306-11.

4. Palstra RJ, Tolhuis B, Splinter E, Nijmeijer R, Grosveld F, de Laat W. The betaglobin nuclear compartment in development and erythroid differentiation. Nat Genet. 2003;35(2):190-4.

5. Tolhuis B, Palstra RJ, Splinter E, Grosveld F, de Laat W. Looping and interaction between hypersensitive sites in the active beta-globin locus. Mol Cell. 2002;10(6):1453-65.

6. Salem T, Gomard T, Court F, Moquet-Torcy G, Brockly F, Forne T, et al. Chromatin loop organization of the junb locus in mouse dendritic cells. Nucleic Acids Res. 2013;41(19):8908-25.

7. Comet I, Schuettengruber B, Sexton T, Cavalli G. A chromatin insulator driving three-dimensional Polycomb response element (PRE) contacts and Polycomb association with the chromatin fiber. Proc Natl Acad Sci U S A. 2011;108(6):2294-9.

8. Tan-Wong SM, French JD, Proudfoot NJ, Brown MA. Dynamic interactions between the promoter and terminator regions of the mammalian BRCA1 gene. Proc Natl Acad Sci U S A. 2008;105(13):5160-5.

9. Ramani V, Cusanovich DA, Hause RJ, Ma W, Qiu R, Deng X, et al. Mapping 3D genome architecture through in situ DNase hi-C. Nat Protoc. 2016; 11(11):2104-21.

10. Harada A, Mallappa C, Okada S, Butler JT, Baker SP, Lawrence JB, et al. Spatial re-organization of myogenic regulatory sequences temporally controls gene expression. Nucleic Acids Res. 2015;43(4):2008-21.

11. Spilianakis CG, Lalioti MD, Town T, Lee GR, Flavell RA. Interchromosomal associations between alternatively expressed loci. Nature. 2005;435(7042):637-45.

12. Zhao Z, Tavoosidana G, Sjolinder M, Gondor A, Mariano P, Wang S, et al Circular chromosome conformation capture (4C) uncovers extensive networks of epigenetically regulated intra- and interchromosomal interactions. Nat Genet. 2006;38(11):1341-7.

13. Simonis $M$, Klous $P$, Splinter $E$, Moshkin $Y$, Willemsen $R$, de Wit $E$, et al. Nuclear organization of active and inactive chromatin domains uncovered by chromosome conformation capture-on-chip (4C). Nat Genet. 2006;38(11):1348-54. 
14. Sexton T, Kurukuti S, Mitchell JA, Umlauf D, Nagano T, Fraser P. Sensitive detection of chromatin coassociations using enhanced chromosome conformation capture on chip. Nat Protoc. 2012;7(7):1335-50.

15. Brouwer RW, van den Hout MC, van IWF, Soler E, Stadhouders R. Unbiased interrogation of 3D genome topology using chromosome conformation capture coupled to high-throughput sequencing (4C-Seq). Methods Mol Biol. 2017;1507:199-220.

16. Dixon JR, Selvaraj S, Yue F, Kim A, Li Y, Shen Y, et al. Topological domains in mammalian genomes identified by analysis of chromatin interactions. Nature. 2012;485(7398):376-80.

17. Ferraiuolo MA, Sanyal A, Naumova N, Dekker J, Dostie J. From cells to chromatin: capturing snapshots of genome organization with $5 \mathrm{C}$ technology. Methods. 2012;58(3):255-67.

18. Dostie J, Dekker J. Mapping networks of physical interactions between genomic elements using 5C technology. Nat Protoc. 2007;2(4):988-1002.

19. Lieberman-Aiden $E$, van Berkum NL, Williams L, Imakaev M, Ragoczy T, Telling $A$, et al. Comprehensive mapping of long-range interactions reveals folding principles of the human genome. Science. 2009;326(5950):289-93.

20. Flyamer IM, Gassler J, Imakaev M, Brandao HB, Ulianov SV, Abdennur N, et al. Single-nucleus hi-C reveals unique chromatin reorganization at oocyte-to-zygote transition. Nature. 2017;544(7648):110-4

21. Belaghzal H, Dekker J, Gibcus JH. Hi-C 2.0: an optimized hi-C procedure for high-resolution genome-wide mapping of chromosome conformation. Methods. 2017;123:56-65.

22. Ramani V, Deng X, Qiu R, Gunderson KL, Steemers FJ, Disteche CM, et al. Massively multiplex single-cell hi-C. Nat Methods. 2017;14(3):263-6.

23. Handoko L, Xu H, Li G, Ngan CY, Chew E, Schnapp M, et al. CTCFmediated functional chromatin interactome in pluripotent cells. Nat Genet. 2011:43(7):630-8.

24. Li G, Ruan X, Auerbach RK, Sandhu KS, Zheng M, Wang P, et al. Extensive promoter-centered chromatin interactions provide a topological basis for transcription regulation. Cell. 2012;148(1-2):84-98.

25. Li G, Chen Y, Snyder MP, Zhang MQ. ChIA-PET2: a versatile and flexible pipeline for ChIA-PET data analysis. Nucleic Acids Res. 2017;45(1):e45.

26. Hughes JR, Roberts N, McGowan S, Hay D, Giannoulatou E, Lynch M, et al. Analysis of hundreds of cis-regulatory landscapes at high resolution in a single, high-throughput experiment. Nat Genet. 2014;46(2):205-12.

27. Kolovos P, van de Werken HJ, Kepper N, Zuin J, Brouwer RW, Kockx CE, et al. Targeted chromatin capture (T2C): a novel high resolution high throughput method to detect genomic interactions and regulatory elements. Epigenetics Chromatin. 2014;7:10.

28. Wachsmuth M, Knoch TA, Rippe K. Dynamic properties of independent chromatin domains measured by correlation spectroscopy in living cells. Epigenetics Chromatin. 2016;9:57.

29. Cairns J, Freire-Pritchett P, Wingett SW, Varnai C, Dimond A, Plagnol V, et al. CHiCAGO: robust detection of DNA looping interactions in capture hi-C data. Genome Biol. 2016;17(1):127

30. Zhang H, Zeitz MJ, Wang H, Niu B, Ge S, Li W, et al. Long noncoding RNAmediated intrachromosomal interactions promote imprinting at the Kcnq1 locus. J Cell Biol. 2014;204(1):61-75.

31. Kang L, Sun J, Wen X, Cui J, Wang G, Hoffman AR, et al. Aberrant alleleswitch imprinting of a novel IGF1R intragenic antisense non-coding RNA in breast cancers. Eur J Cancer. 2015;51(2):260-70.

32. Dekker J. Mapping the 3D genome: aiming for consilience. Nat Rev Mol Cell Biol. 2016;17(12):741-2

33. Beagrie RA, Scialdone A, Schueler M, Kraemer DC, Chotalia M, Xie SQ, et al. Complex multi-enhancer contacts captured by genome architecture mapping. Nature. 2017;543(7646):519-24.

34. Liu X, Zhang Y, Chen Y, Li M, Zhou F, Li K, et al. In situ capture of chromatin interactions by Biotinylated dCas9. Cell. 2017;170(5):1028-43. e19

35. Wei J, Czapla L, Grosner MA, Swigon D, Olson WK. DNA topology confers sequence specificity to nonspecific architectural proteins. Proc Natl Acad Sci U S A. 2014;111(47):16742-7.

36. Diesinger PM, Kunkel S, Langowski J, Heermann DW. Histone depletion facilitates chromatin loops on the kilobasepair scale. Biophys J. 2010;99(9): 2995-3001.

37. Shore D, Baldwin RL. Energetics of DNA twisting. I. Relation between twist and cyclization probability. J Mol Biol. 1983;170(4):957-81.

38. Polikanov YS, Bondarenko VA, Tchernaenko V, Jiang YI, Lutter LC, Vologodskii A, et al. Probability of the site juxtaposition determines the rate of protein-mediated DNA looping. Biophys J. 2007;93(8):2726-31.
39. Sanyal A, Lajoie BR, Jain G, Dekker J. The long-range interaction landscape of gene promoters. Nature. 2012;489(7414):109-13.

40. Rao SS, Huntley MH, Durand NC, Stamenova EK, Bochkov ID, Robinson JT, et al. A 3D map of the human genome at kilobase resolution reveals principles of chromatin looping. Cell. 2014;159(7):1665-80.

41. Du Z, Zheng H, Huang B, Ma R, Wu J, Zhang X, et al. Allelic reprogramming of $3 \mathrm{D}$ chromatin architecture during early mammalian development. Nature. 2017;547(7662):232-5.

42. Ke Y, Xu Y, Chen X, Feng S, Liu Z, Sun Y, et al. 3D chromatin structures of mature gametes and structural reprogramming during mammalian embryogenesis. Cell. 2017;170(2):367-81. e20

43. Nagano T, Lubling Y, Várnai C, Dudley C, Leung W, Baran Y, et al. Cell-cycle dynamics of chromosomal organization at single-cell resolution. Nature. 2017; 547(7661):61-7.

44. Vietri Rudan M, Barrington C, Henderson S, Ernst C, Odom DT, Tanay A, et al. Comparative hi-C reveals that CTCF underlies evolution of chromosomal domain architecture. Cell Rep. 2015;10(8):1297-309.

45. Guo Y, Xu Q, Canzio D, Shou J, Li J, Gorkin DU, et al. CRISPR inversion of CTCF sites alters genome topology and enhancer/promoter function. Cell. 2015;162(4):900-10.

46. Mora A, Sandve GK, Gabrielsen OS, Eskeland R. In the loop: promoterenhancer interactions and bioinformatics. Brief Bioinform. 2016;17(6):980-95.

47. Hansen AS, Pustova I, Cattoglio C, Tjian R, Darzaca X. CTCF and cohesin regulate chromatin loop stability with distinct dynamics. Elife. 2017;6. https://elifesciences.org/articles/25776.

48. Carroll JS, Liu XS, Brodsky AS, Li W, Meyer CA, Szary AJ, et al. Chromosomewide mapping of estrogen receptor binding reveals long-range regulation requiring the forkhead protein FoxA1. Cell. 2005;122(1):33-43.

49. Hu Q, Kwon YS, Nunez E, Cardamone MD, Hutt KR, Ohgi KA, et al. Enhancing nuclear receptor-induced transcription requires nuclear motor and LSD1-dependent gene networking in interchromatin granules. Proc Natl Acad Sci U S A. 2008;105(49):19199-204.

50. Tan SK, Lin ZH, Chang CW, Varang V, Chng KR, Pan YF, et al. AP-2gamma regulates oestrogen receptor-mediated long-range chromatin interaction and gene transcription. EMBO J. 2011;30(13):2569-81.

51. Zhang $Y$, Wong $C H$, Birnbaum RY, Li G, Favaro R, Ngan CY, et al. Chromatin connectivity maps reveal dynamic promoter-enhancer long-range associations. Nature. 2013:504(7479):306-10.

52. Chen Z, Zhang C, Wu D, Chen H, Rorick A, Zhang X, et al. Phospho-MED1enhanced UBE2C locus looping drives castration-resistant prostate cancer growth. EMBO J. 2011;30(12):2405-19.

53. Arthur RK, An N, Khan S, McNerney ME. The haploinsufficient tumor suppressor, CUX1, acts as an analog transcriptional regulator that controls target genes through distal enhancers that loop to target promoters. Nucleic Acids Res. 2017;45(11):6350-361. doi:10.1093/nar/gkx218.

54. Riley KJ, Steitz JA. The "observer effect" in genome-wide surveys of proteinRNA interactions. Mol Cell. 2013:49(4):601-4

55. Hadjur S, Williams LM, Ryan NK, Cobb BS, Sexton T, Fraser $P$, et al. Cohesins form chromosomal cis-interactions at the developmentally regulated IFNG locus. Nature. 2009;460(7253):410-3

56. Wang H, Li W, Guo R, Sun J, Cui J, Wang G, et al. An intragenic long noncoding RNA interacts epigenetically with the RUNX1 promoter and enhancer chromatin DNA in hematopoietic malignancies. Int J Cancer. 2014;135(12):2783-94.

57. Wu D, Zhang C, Shen Y, Nephew KP, Wang Q. Androgen receptor-driven chromatin looping in prostate cancer. Trends Endocrinol Metab. 2011:22(12):474-80.

58. Lin C, Yang L, Tanasa B, Hutt K, Ju BG, Ohgi K, et al. Nuclear receptorinduced chromosomal proximity and DNA breaks underlie specific translocations in cancer. Cell. 2009;139(6):1069-83.

59. Takayama K, Kaneshiro K, Tsutsumi S, Horie-Inoue K, Ikeda K, Urano T, et al. Identification of novel androgen response genes in prostate cancer cells by coupling chromatin immunoprecipitation and genomic microarray analysis. Oncogene. 2007;26(30):4453-63.

60. Wang Q, Li W, Liu XS, Carroll JS, Janne OA, Keeton EK, et al. A hierarchical network of transcription factors governs androgen receptor-dependent prostate cancer growth. Mol Cell. 2007;27(3):380-92.

61. Yu J, Yu J, Mani RS, Cao Q, Brenner CJ, Cao X, et al. An integrated network of androgen receptor, polycomb, and TMPRSS2-ERG gene fusions in prostate cancer progression. Cancer Cell. 2010;17(5):443-54.

62. Wang Q, Carroll JS, Brown M. Spatial and temporal recruitment of androgen receptor and its coactivators involves chromosomal looping and polymerase tracking. Mol Cell. 2005;19(5):631-42. 
63. Elemento O, Rubin MA, Rickman DS. Oncogenic transcription factors as master regulators of chromatin topology: a new role for ERG in prostate cancer. Cell Cycle. 2012;11(18):3380-3.

64. Rickman DS, Soong TD, Moss B, Mosquera JM, Dlabal J, Terry S, et al. Oncogene-mediated alterations in chromatin conformation. Proc Natl Acad Sci U S A. 2012;109(23):9083-8.

65. Taberlay PC, Achinger-Kawecka J, Lun AT, Buske FA, Sabir K, Gould CM, et al. Three-dimensional disorganization of the cancer genome occurs coincident with long-range genetic and epigenetic alterations. Genome Res. 2016;26(6):719-31.

66. Yang L, Lin C, Jin C, Yang JC, Tanasa B. Li W, et al. IncRNA-dependent mechanisms of androgen-receptor-regulated gene activation programs. Nature. 2013;500(7464):598-602.

67. Scully T, Firth SM, Scott CD, de Silva HC, Pintar JE, Chan-Ling T, et al. Insulinlike growth factor binding protein-3 links obesity and breast cancer progression. Oncotarget. 2016;7(34):55491-505

68. Zeitz MJ, Ay F, Heidmann JD, Lerner PL, Noble WS, Steelman BN, et al. Genomic interaction profiles in breast cancer reveal altered chromatin architecture. PLoS One. 2013;8(9):e73974.

69. Theodorou V, Stark R, Menon S, Carroll JS. GATA3 acts upstream of FOXA in mediating ESR1 binding by shaping enhancer accessibility. Genome Res. 2013;23(1):12-22.

70. Holmes KA, Hurtado A, Brown GD, Launchbury R, Ross-Innes CS, Hadfield J, et al. Transducin-like enhancer protein 1 mediates estrogen receptor binding and transcriptional activity in breast cancer cells. Proc Natl Acad Sci U S A. 2012;109(8):2748-53.

71. Magnani L, Ballantyne EB, Zhang X, Lupien M. PBX1 genomic pioneer function drives ERalpha signaling underlying progression in breast cancer. PLoS Genet. 2011;7(11):e1002368.

72. Phillips-Cremins JE, Sauria ME, Sanyal A, Gerasimova TI, Lajoie BR, Bell JS, et al. Architectural protein subclasses shape 3D organization of genomes during lineage commitment. Cell. 2013;153(6):1281-95.

73. Schmidt D, Schwalie PC, Ross-Innes CS, Hurtado A, Brown GD, Carroll JS, et al. A CTCF-independent role for cohesin in tissue-specific transcription. Genome Res. 2010;20(5):578-88.

74. Mourad R, Hsu PY, Juan L, Shen C, Koneru P, Lin H, et al. Estrogen induces global reorganization of chromatin structure in human breast cancer cells. PLoS One. 2014;9(12):e113354.

75. Barutcu AR, Hong D, Lajoie BR, McCord RP, van Wijnen AJ, Lian JB, et al. RUNX1 contributes to higher-order chromatin organization and gene regulation in breast cancer cells. Biochim Biophys Acta. 2016; 1859(11):1389-97.

76. Fullwood MJ, Liu MH, Pan YF, Liu J, Xu H, Mohamed YB, et al. An oestrogen-receptor-alpha-bound human chromatin interactome. Nature. 2009;462(7269):58-64.

77. Qiao Y, Shiue CN, Zhu J, Zhuang T, Jonsson P, Wright AP, et al. AP-1mediated chromatin looping regulates ZEB2 transcription: new insights into TNFalpha-induced epithelial-mesenchymal transition in triple-negative breast cancer. Oncotarget. 2015;6(10):7804-14.

78. Espinal-Enriquez J, Fresno C, Anda-Jauregui G, Hernandez-Lemus E. RNA-Seq based genome-wide analysis reveals loss of inter-chromosomal regulation in breast cancer. Sci Rep. 2017;7(1):1760.

79. Groschel S, Sanders MA, Hoogenboezem R, de Wit E, Bouwman BA, Erpelinck $C$, et al. A single oncogenic enhancer rearrangement causes concomitant EVI1 and GATA2 deregulation in leukemia. Cell. 2014; 157(2):369-81.

80. Shugay M, Ortiz de Mendibil I, Vizmanos JL, Novo FJ. Genomic hallmarks of genes involved in chromosomal translocations in hematological cancer. PLoS Comput Biol. 2012;8(12):e1002797.

81. Wang Z, Cao R, Taylor K, Briley A, Caldwell C, Cheng J. The properties of genome conformation and spatial gene interaction and regulation networks of normal and malignant human cell types. PLoS One. 2013; 8(3):e58793.

82. Sun J, Li W, Sun Y, Yu D, Wen X, Wang H, et al. A novel antisense long noncoding RNA within the IGF1R gene locus is imprinted in hematopoietic malignancies. Nucleic Acids Res. 2014;42(15):9588-601.

83. Katainen R, Dave K, Pitkanen E, Palin K, Kivioja T, Valimaki N, et al. CTCF/ cohesin-binding sites are frequently mutated in cancer. Nat Genet. 2015; 47(7):818-21.

84. Xiang JF, Yin QF, Chen T, Zhang Y, Zhang XO, Wu Z, et al. Human colorectal cancer-specific CCAT1-L IncRNA regulates long-range chromatin interactions at the MYC locus. Cell Res. 2014;24(5):513-31.
85. Kim IS, Heilmann S, Kansler ER, Zhang Y, Zimmer M, Ratnakumar K, et al Microenvironment-derived factors driving metastatic plasticity in melanoma. Nat Commun. 2017:8:14343.

86. Bastonini E, Jeznach M, Field M, Juszczyk K, Corfield E, Dezfouli M, et al. Chromatin barcodes as biomarkers for melanoma. Pigment Cell Melanoma Res. 2014;27(5):788-800.

87. Hamby SE, Reviriego P, Cooper DN, Upadhyaya M, Chuzhanova N. Screening in silico predicted remotely acting NF1 gene regulatory elements for mutations in patients with neurofibromatosis type 1. Hum Genomics. 2013;7:18.

88. Drier Y, Cotton MJ, Williamson KE, Gillespie SM, Ryan RJ, Kluk MJ, et al. An oncogenic MYB feedback loop drives alternate cell fates in adenoid cystic carcinoma. Nat Genet. 2016;48(3):265-72.

89. Martin JS, Xu Z, Reiner AP, Mohlke KL, Sullivan P, Ren B, et al. HUGIn: Hi-C Unifying Genomic Interrogator. Bioinformatics. 2017. doi:10.1093/ bioinformatics/bt×359

90. Du M, Tillmans L, Gao J, Gao P, Yuan T, Dittmar RL, et al. Chromatin interactions and candidate genes at ten prostate cancer risk loci. Sci Rep. 2016;6:23202.

91. Cai M, Kim S, Wang K, Farnham PJ, Coetzee GA, Lu W. 4C-seq revealed long-range interactions of a functional enhancer at the $8 q 24$ prostate cancer risk locus. Sci Rep. 2016;6:22462.

92. Tordini F, Aldinucci M, Milanesi L, Lio P, Merelli I. The genome conformation as an integrator of multi-Omic data: the example of damage spreading in cancer. Front Genet. 2016;7:194

93. Dryden NH, Broome LR, Dudbridge F, Johnson N, Orr N, Schoenfelder S, et al. Unbiased analysis of potential targets of breast cancer susceptibility loci by capture hi-C. Genome Res. 2014;24(11):1854-68.

94. Sotelo J, Esposito D, Duhagon MA, Banfield K, Mehalko J, Liao H, et al. Longrange enhancers on 8q24 regulate c-Myc. Proc Natl Acad Sci U S A. 2010; 107(7):3001-5.

95. Jager R, Migliorini G, Henrion M, Kandaswamy R, Speedy HE, Heindl A, et al. Capture hi-C identifies the chromatin interactome of colorectal cancer risk loci. Nat Commun. 2015;6:6178.

96. Hoskins JW, Ibrahim A, Emmanuel MA, Manmiller SM, Wu Y, O'Neill M, et al. Functional characterization of a chr13q22.1 pancreatic cancer risk locus reveals long-range interaction and allele-specific effects on DIS3 expression. Hum Mol Genet. 2016;25(21):4726-38

97. He H, Li W, Liyanarachchi S, Srinivas M, Wang Y, Akagi K, et al. Multiple functional variants in long-range enhancer elements contribute to the risk of SNP rs965513 in thyroid cancer. Proc Natl Acad Sci U S A. 2015;112(19):6128-33.

98. Ing-Simmons E, Merkenschlager M. Oncometabolite tinkers with genome folding, boosting Oncogene expression. Trends Mol Med. 2016;22(3):185-7.

99. Baskin R, Woods NT, Mendoza-Fandino G, Forsyth P, Egan KM, Monteiro AN. Functional analysis of the 11q23.3 glioma susceptibility locus implicates PHLDB1 and DDX6 in glioma susceptibility. Sci Rep. 2015;5:17367.

100. Litchfield K, Levy M, Orlando G, Loveday C, Law PJ, Migliorini G, et al. Identification of 19 new risk loci and potential regulatory mechanisms influencing susceptibility to testicular germ cell tumor. Nat Genet. 2017;49(7):1133-40.

101. Harewood L, Kishore K, Eldridge MD, Wingett S, Pearson D, Schoenfelder S, et al. $\mathrm{Hi}-\mathrm{C}$ as a tool for precise detection and characterisation of chromosomal rearrangements and copy number variation in human tumours. Genome Biol. 2017;18(1):125.

102. Tomlins SA, Day JR, Lonigro RJ, Hovelson DH, Siddiqui J, Kunju LP, et al. Urine TMPRSS2:ERG plus PCA3 for individualized prostate cancer risk assessment. Eur Urol. 2016:70(1):45-53.

103. Robert G, Jannink S, Smit F, Aalders T, Hessels D, Cremers R, et al. Rational basis for the combination of PCA3 and TMPRSS2:ERG gene fusion for prostate cancer diagnosis. Prostate. 2013;73(2):113-20.

104. Hagglof C, Hammarsten P, Stromvall K, Egevad L, Josefsson A, Stattin P, et al. TMPRSS2-ERG expression predicts prostate cancer survival and associates with stromal biomarkers. PLoS One. 2014;9(2):e86824.

105. Baccarani M, Deininger MW, Rosti G, Hochhaus A, Soverini S, Apperley JF, et al. European LeukemiaNet recommendations for the management of chronic myeloid leukemia: 2013. Blood. 2013;122(6):872-84.

106. Rousseau M, Ferraiuolo MA, Crutchley JL, Wang XQ, Miura H, Blanchette M, et al. Classifying leukemia types with chromatin conformation data. Genome Biol. 2014;15(4):R60.

107. Law PJ, Sud A, Mitchell JS, Henrion M, Orlando G, Lenive O, et al. Genomewide association analysis of chronic lymphocytic leukaemia, Hodgkin lymphoma and multiple myeloma identifies pleiotropic risk loci. Sci Rep. 2017;7:41071. 
108. McNerney ME, Brown CD, Wang X, Bartom ET, Karmakar S, Bandlamudi C, et al. CUX1 is a haploinsufficient tumor suppressor gene on chromosome 7 frequently inactivated in acute myeloid leukemia. Blood. 2013;121(6):975-83.

109. Kang Y, Pantel K. Tumor cell dissemination: emerging biological insights from animal models and cancer patients. Cancer Cell. 2013;23(5):573-81.

110. Davison LJ, Wallace C, Cooper JD, Cope NF, Wilson NK, Smyth DJ, et al. Long-range DNA looping and gene expression analyses identify DEXI as an autoimmune disease candidate gene. Hum Mol Genet. 2012;21(2):322-33.

111. Smemo S, Tena JJ, Kim KH, Gamazon ER, Sakabe NJ, Gomez-Marin C, et al. Obesity-associated variants within FTO form long-range functional connections with IRX3. Nature. 2014;507(7492):371-5.

112. Leng $Q$, Mixson AJ. The neuropilin-1 receptor mediates enhanced tumor delivery of H2K polyplexes. J Gene Med. 2016;18(7):134-44.

113. Luo Y, Wu JY, Lu MH, Shi Z, Na N, Di JM. Carvacrol alleviates prostate cancer cell proliferation, migration, and invasion through regulation of PI3K/Akt and MAPK signaling pathways. Oxidative Med Cell Longev. 2016;2016:1469693.

114. Saura C, Roda D, Rosello S, Oliveira M, Macarulla T, Perez-Fidalgo JA, et al. A first-in-human phase I study of the ATP-competitive AKT inhibitor Ipatasertib demonstrates robust and safe targeting of AKT in patients with solid tumors. Cancer Discovery. 2017;7(1):102-13.

115. Wei XX, Hsieh AC, Kim W, Friedlander T, Lin AM, Louttit M, et al. A phase I study of abiraterone acetate combined with BEZ235, a dual PI3K/mTOR inhibitor, in metastatic castration resistant prostate cancer. Oncologist. 2017;22(5):503-e43.

116. Fizazi K, Flaig TW, Stockle M, Scher HI, de Bono JS, Rathkopf DE, et al. Does Gleason score at initial diagnosis predict efficacy of abiraterone acetate therapy in patients with metastatic castration-resistant prostate cancer? An analysis of abiraterone acetate phase III trials. Ann Oncol. 2016;27(4):699-705.

117. Thomas JD, Longen CG, Oyer HM, Chen N, Maher CM, Salvino JM, et al. Sigma1 targeting to suppress aberrant androgen receptor signaling in prostate cancer. Cancer Res. 2017;77(9):2439-52.

118. Liu C, Armstrong C, Zhu Y, Lou W, Gao AC. Niclosamide enhances abiraterone treatment via inhibition of androgen receptor variants in castration resistant prostate cancer. Oncotarget. 2016;7(22):32210-20.

119. Lai KP, Huang CK, Chang YJ, Chung CY, Yamashita S, Li L, et al. New therapeutic approach to suppress castration-resistant prostate cancer using ASC-J9 via targeting androgen receptor in selective prostate cells. Am J Pathol. 2013;182(2):460-73.

120. Myung JK, Banuelos CA, Fernandez JG, Mawji NR, Wang J, Tien AH, et al. An androgen receptor $\mathrm{N}$-terminal domain antagonist for treating prostate cancer. J Clin Invest. 2013;123(7):2948-60.

121. Gong AY, Eischeid AN, Xiao J, Zhao J, Chen D, Wang ZY, et al. miR-17-5p targets the p300/CBP-associated factor and modulates androgen receptor transcriptional activity in cultured prostate cancer cells. BMC Cancer. 2012;12:492.

122. Schmitt AM, Chang HY. Gene regulation: long RNAs wire up cancer growth. Nature. 2013;500(7464):536-7.

123. Zhang A, Zhao JC, Kim J, Fong KW, Yang YA, Chakravarti D, et al. LncRNA HOTAIR enhances the androgen-receptor-mediated transcriptional program and drives castration-resistant prostate cancer. Cell Rep. 2015;13(1):209-21.

124. Guo C, Yeh S, Niu Y, Li G, Zheng J, Li L, et al. Targeting androgen receptor versus targeting androgens to suppress castration resistant prostate cancer. Cancer Lett. 2017;397:133-43.

125. Grimison PS, Stockler MR, Chatfield M, Thomson DB, Gebski V, Friedlander $M$, et al. Accelerated BEP for metastatic germ cell tumours: a multicenter phase II trial by the Australian and New Zealand Urogenital and prostate cancer trials group (ANZUP). Ann Oncol. 2014;25(1):143-8.

126. Haffner MC, Aryee MJ, Toubaji A, Esopi DM, Albadine R, Gurel B, et al. Androgen-induced TOP2B-mediated double-strand breaks and prostate cancer gene rearrangements. Nat Genet. 2010;42(8):668-75.

127. Tan J, Yang $X$, Zhuang $L$, Jiang $X$, Chen $W$, Lee $P L$, et al. Pharmacologic disruption of Polycomb-repressive complex 2-mediated gene repression selectively induces apoptosis in cancer cells. Genes Dev. 2007;21(9):1050-63.

128. McCabe MT, Ott HM, Ganji G, Korenchuk S, Thompson C, Van Aller GS, et al. EZH2 inhibition as a therapeutic strategy for lymphoma with EZH2activating mutations. Nature. 2012;492(7427):108-12.

129. Wang X, Qiao Y, Asangani IA, Ateeq B, Poliakov A, Cieslik M, et al. Development of Peptidomimetic inhibitors of the ERG gene fusion product in prostate cancer. Cancer Cell. 2017;31(4):532-48. e7

130. Gonzalez-Rubio S, Linares Cl, Aguilar-Melero P, Rodriguez-Peralvarez M, Montero-Alvarez JL, de la Mata M, et al. AP-1 inhibition by SR 11302 protects human Hepatoma HepG2 cells from bile acid-induced Cytotoxicity by restoring the NOS-3 expression. PLoS One. 2016;11(8):e0160525.
131. Zhang C, Liu S, Yuan X, Hu Z, Li H, Wu M, et al. Valproic acid promotes human Glioma U87 cells apoptosis and inhibits glycogen Synthase Kinase3beta through ERK/Akt signaling. Cell Physiol Biochem. 2016;39(6):2173-85.

132. Zheng YB, Luo HP, Shi Q, Hao ZN, Ding Y, Wang QS, et al. miR-132 inhibits colorectal cancer invasion and metastasis via directly targeting ZEB2. World J Gastroenterol. 2014;20(21):6515-22.

133. Munster P, Marchion D, Bicaku E, Lacevic M, Kim J, Centeno B, et al. Clinical and biological effects of valproic acid as a histone deacetylase inhibitor on tumor and surrogate tissues: phase I/II trial of valproic acid and epirubicin/ FEC. Clin Cancer Res. 2009;15(7):2488-96.

134. Syed J, Pandian GN, Sato S, Taniguchi J, Chandran A, Hashiya K, et al. Targeted suppression of EVI1 oncogene expression by sequence-specific pyrrole-imidazole polyamide. Chem Biol. 2014;21(10):1370-80.

135. Lu X, Zhang Z, Ren X, Wang D, Ding K. Synthesis and identification of GZD856 as an orally bioavailable Bcr-AblT315I inhibitor overcoming acquired imatinib resistance. J Enzyme Inhib Med Chem. 2017;32(1):331-6.

136. Krishna P, Sarvagalla S, Madhuri B, Pajaniradje S, Baskaran V, Coumar MS, et al. Identification of Natural inhibitors of Bcr-Abl for the treatment of Chronic Myeloid Leukemia. Chem Biol Drug Des. 2017;90(4):596-608.

137. Deeks ED. Venetoclax: First Global Approval. Drugs. 2016;76(9):979-87.

138. Kim H, Ronai ZA. HIV drug to aid melanoma therapies? Cancer Cell. 2016; 29(3):245-6.

139. Ember SW, Lambert QT, Berndt N, Gunawan S, Ayaz M, Tauro M, et al. Potent dual BET bromodomain-kinase inhibitors as value added multitargeted chemical probes and cancer therapeutics. In: Molecular cancer therapeutics; 2017.

140. Loven J, Hoke HA, Lin CY, Lau A, Orlando DA, Vakoc CR, et al. Selective inhibition of tumor oncogenes by disruption of super-enhancers. Cell. 2013; 153(2):320-34.

141. Xu S, Wang H, Pan H, Shi Y, Li T, Ge S, et al. ANRIL IncRNA triggers efficient therapeutic efficacy by reprogramming the aberrant INK4-hub in melanoma. Cancer Lett. 2016;381(1):41-8.

142. Davies JO, Oudelaar AM, Higgs DR, Hughes JR. How best to identify chromosomal interactions: a comparison of approaches. Nat Methods. 2017; 14(2):125-34.

\section{Submit your next manuscript to BioMed Central and we will help you at every step:}

- We accept pre-submission inquiries

- Our selector tool helps you to find the most relevant journal

- We provide round the clock customer support

- Convenient online submission

- Thorough peer review

- Inclusion in PubMed and all major indexing services

- Maximum visibility for your research

Submit your manuscript at www.biomedcentral.com/submit
Biomed Central 